\title{
Entre a herança e a presença: o patrimônio cultural de referência negra no Rio de Janeiro'
}

\author{
Between inheritance and presence: the cultural heritage of black reference in
} Rio de Janeiro

https://doi.org/10.1590/1982-02672020v28d2e50

\section{MÁRCIA REGINA ROMEIRO CHUVA²}

https:/ / orcid.org/0000-0003-4942-688 1

Universidade Federal do Estado do Rio de Janeiro / Rio de Janeiro, RJ, Brasil

RESUMO: Este artigo analisa ações dirigidas ao reconhecimento da herança negra por meio de políticas de memória e patrimônio durante o primeiro governo do estado do Rio de Janeiro eleito democraticamente nos anos 1980, especialmente o tombamento da Pedra do Sal e a instalação do Monumento a Zumbi. Para compreender essas ações, é feita, inicialmente, uma leitura sobre os modos como as políticas de patrimônio em nível federal foram transformadas no contexto da redemocratização do país e estiveram em diálogo com as políticas implementadas no nível estadual do Rio de Janeiro. Este texto busca perceber os paradigmas que fundamentam tais narrativas, ao mesmo tempo que transita da macropolítica ao campo das lutas de memória, como universos entrelaçados. Na segunda parte, analisamse eventos relacionados à patrimonialização da herança negra na cidade, nos anos 2000, a saber, o reconhecimento da Pedra do Sal como quilombo, em 2005, e os títulos de Patrimônio Mundial atribuídos à cidade pela Unesco, em 2012 e 2017 . Busca-se, assim, capturar as representações da cidade patrimonializada e verificar os valores que prevalecem em cada situação, identificando a presença de dois paradigmas que tensionam o campo do patrimônio, aqui chamados de paradigma moderno e paradigma do patrimônio como direito. A noção de valor histórico acionada nas situações analisadas será um dos fios condutores por meio dos quais são estabelecidas conexões analíticas entre os paradigmas de patrimônio, os regimes de historicidade e as percepções de tempo passado e tempo presente.

\begin{abstract}
1. Esta pesquisa faz parte das atividades do projeto ECHOES (European Colonial Heritage Modalities in Entangles Cities), financiado pela União Europeia, Edital Horizon 2020 - Programa Pesquisa e Inovação, acordo n.7770248.
\end{abstract}

2. Doutora em História pela Universidade Federal Fluminense (UFF), com pós-doutorado na Universidade de Coimbra.É pesquisadora do $\mathrm{CNPq}$, professora associada do Departamento de História e do Programa de Pós-Graduação em História da Universidade Federal do Estado do Rio de Janeiro (Unirio) e do Mestrado Profissional em Patrimônio Cultural do Instituto do Patrimônio Histórico e Artístico Nacional (Iphan). E-mail: $<$ marciachuva@gmail.com>. 
PALAVRAS-CHAVE: Pedra do Sal. Monumento a Zumbi. Rio de Janeiro. Políticas de memória e patrimônio. Valor histórico. Herança negra.

ABSTRACT: This article analyzes actions taken to acknowledge black inheritance through policies of memory and heritage during the first democratically elected government of the state of Rio de Janeiro in the 1980s, especially the protection of Pedra do Sal and the Monument to Zumbi. In order to understand these actions, firstly, the ways in which heritage policies at the federal level were transformed in the context of the country's redemocratization are analyzed, and how they were in dialogue with the policies implemented at the state level of Rio de Janeiro. We verify the paradigms that underlie such narratives, while moving from macropolitics to the field of struggles of memory as intertwined universes. In the second section, events related to the patrimonialization of black heritage in the city in the 2000s are analyzed, namely, the recognition of Pedra do Sal as Quilombo in 2005, and the world heritage titles attributed to the city by Unesco in 2012 and 2017. Thus, it seeks to capture the representations of the heritage city and verify the values that prevail in each situation, identifying the presence of two paradigms that tension the field of heritage, here called the modern paradigm and the paradigm of heritage as a right. The notion of historical value triggered in the analyzed situations is one of the guiding threads through which analytical connections are established between heritage paradigms, historicity regimes, and the perceptions of past and present time.

KEYWORDS: Pedra do Sal. Monument to Zumbi. Rio de Janeiro. Memory and heritage policies. Historical value. Black inheritance. 
"A festa de inauguração será um ato sem discursos, onde deverá haver uma sinfonia de atabaques para lembrar que o Rio é uma cidade negra". ${ }^{3}$ Com essas palavras, Darcy Ribeiro anunciava na grande imprensa como planejava a inauguração do Monumento a Zumbi dos Palmares, no Rio de Janeiro. Em 1986, o antropólogo, ocupando o cargo de vice-governador do Rio de Janeiro e de secretário de Cultura, queria lembrar a todos que o Rio era uma cidade negra. Ações emblemáticas de memória e patrimônio foram implementadas nesse governo, que em sua estratégia de poder progressivamente se aproximou da pauta do movimento negro, nos anos 1980, quando da redemocratização do país. Teria o Rio de Janeiro se tornado uma cidade negra na imaginação nacional e carioca, como desejou Darcy?

Se buscarmos respostas a essa pergunta nas imagens do Rio divulgadas nos canais de mídia, propaganda e turismo, encontraremos um rotundo não. Mas se, em vez de uma imagem fixa, buscarmos as dinâmicas que confrontam várias imagens da cidade, podemos, nos limites de um estudo sobre políticas de patrimônio, escapar de uma leitura simplista e linear dos processos que envolvem a herança e a presença negra no Rio de Janeiro e trazer elementos para pensar sobre tal pergunta, que motivou a escrita deste artigo.

Serão analisadas, primeiramente, ações emblemáticas e inaugurais dirigidas ao reconhecimento da herança negra, realizadas por meio de políticas de memória e patrimônio durante o primeiro governo do estado do Rio de Janeiro eleito democraticamente nos anos 1980, com destaque para o tombamento da Pedra do Sal em 1984 e a inauguração do Monumento a Zumbi dos Palmares em 1986. Previamente, contextualizaremos o campo do patrimônio nos anos 1980, a partir da instituição federal, para evidenciar atitudes que podem ser relacionadas ao processo de redemocratização do país.

Em seguida, daremos um salto no tempo para os eventos relacionados à patrimonialização da herança negra na cidade nos anos 2000, como o reconhecimento oficial da Pedra do Sal como quilombo em 2005, e os títulos de Patrimônio Mundial atribuídos à cidade pela Organização das Nações Unidas para a Educação, a Ciência e a Cultura (Unesco), em 2012 e 2017. A intenção é compreender os modos como a herança negra representa (ou não) a cidade patrimonializada e verificar como se relacionam com as anteriores narrativas de patrimônio, considerando o novo contexto político brasileiro e mundial e, quiçá, os novos paradigmas em cena no campo do patrimônio. 
Nas situações analisadas, encontramos perspectivas de patrimônio concorrentes, que convivem, disputam e transformam a cidade. Essa diversidade é indício, no meu entender, da presença de diferentes paradigmas nas políticas de patrimônio no Brasil, cujos interlocutores disputam posições e também o poder de ação e intervenção. As políticas de patrimônio refletem contradições sociais e lutas políticas e resultam de consensos provisórios, conquistados palmo a palmo em negociações por recursos e diretrizes, no interior dos órgãos de patrimônio, marcados também pela interação com diferentes setores, pressões e demandas sociais.

Metodologicamente, propomos uma abordagem das políticas de memória e patrimônio como parte do campo político tout courte, para tanto, vamos transitar da macropolítica ao campo das lutas de memória, como universos entrelaçados. Para uma análise dos valores de patrimônio atribuídos, em especial do valor histórico, privilegiamos, de modo geral, a documentação dos órgãos de patrimônio, em que podemos verificar as narrativas do valor atribuído aos bens em foco, bem como certas tensões presentes no momento dos debates. Como documentação dos anos 1980, levantamos processos de tombamento do Instituto do Patrimônio Histórico e Artístico Nacional (Iphan) e atas das reuniões do Conselho Consultivo em que foram julgados, além do processo de tombamento da Pedra do Sal, do Instituto Estadual do Patrimônio Cultural (Inepac). Juntamos a esse material empírico institucional reportagens da grande imprensa acerca da construção e inauguração do Monumento a Zumbi dos Palmares e sobre o tombamento da Pedra do Sal. A Revista do Patrimônio Histórico e Artístico Nacional dessa mesma década foi vista em conjunto, buscando uma leitura do novo projeto editorial, bem como dos temas em debate na época. Para a análise dos anos 2000, privilegiamos os dois dossiês de Patrimônio Mundial do Rio de Janeiro (de 2012 e 2017) e o Relatório técnico de identificação e delimitação da comunidade remanescente do Quilombo de Pedra do Sal. Nesses documentos, podemos verificar as narrativas de valor que subsidiaram suas decisões.

\section{ANOS 1980: POLÍTICA E PATRIMÔNIO}

Conquistas políticas e novos marcos legais se desenharam com o fim da ditadura militar no Brasil, nos anos 1980, efetivamente selado com a Constituição Federal de 1988. Em nível federal, José Sarney assumira a Presidência da República em 1985, por meio de eleições indiretas, e durante seu governo foram instaurados não somente os trabalhos da Assembleia Nacional Constituinte, mas também as eleições diretas para presidente, em 1989, após sua suspensão por 
quase três décadas - desde o estabelecimento do regime militar no país com o golpe de 1964. Também data dos anos 1980 a restauração das eleições livres e diretas para os governos estaduais e as prefeituras das capitais dos estados, igualmente suspensas durante todo o período ditatorial.

A redemocratização do país, com a recomposição das instituições republicanas, também atingia as políticas de patrimônio e, diretamente, o órgão federal criado em 1937, o lphan. Sob a direção do designer Aloísio Magalhães a partir de 1979, foram executadas ações de renovação do modo de gerir a agência federal. ${ }^{4}$ Sua morte prematura em 1982 produziu incertezas e um rearranjo de forças dentro da instituição. Nos anos seguintes, ao longo da década de 1980, buscou-se dar continuidade à implantação da Fundação Nacional Pró-Memória (PróMemória) como braço executivo do órgão federal. Criada na gestão de Aloísio, a PróMemória reestruturou um conjunto de instituições federais de cultura e memória que há anos se encontravam em franco abandono. ${ }^{5}$

Para compreendermos o novo cenário institucional que se desenhava para a implementação das políticas de patrimônio, destacamos a criação de um setor de editoração e comunicação na PróMemória como uma das principais ações de modernização implementadas por Aloísio Magalhães, pois através dela podemos verificar uma clara preocupação com a capacidade de diálogo do órgão com a sociedade e a divulgação das suas atribuições. A editoração da Secretaria do Patrimônio Histórico e Artístico Nacional (Sphan) e da Fundação Nacional PróMemória (PróMemória) foi coordenada por profissionais que trabalharam com o designer no Centro Nacional de Referência Cultural (CNRC) entre 1975 e 1979. Esse setor promoveu uma verdadeira revolução no marketing institucional ao criar canais próprios de comunicação. Até então, a instituição fazia uso recorrente dos jornais de grande circulação para publicizar suas ações, posições e opiniões, restringindo-se, contudo, a esse canal, de forma esporádica e eventual.

Nos anos 1980 foi criado o Boletim Sphan/Pró-Memória, ${ }^{\circ}$ com periodicidade mensal e ampla tiragem para distribuição em todo o território nacional, e retomada a publicação da Revista do Patrimônio Histórico e Artístico Nacional,7 o mais antigo canal de veiculação dos estudos sobre o patrimônio cultural brasileiro, criado em 1937. A Revista teve seu projeto editorial radicalmente transformado: ganhou novo formato, com nova linguagem visual e uma comunicação mais direta com os leitores, apresentando-se como um espaço de discussão e controvérsias até então inexistente nesse periódico.

Os números 19, 20 e 21 llançados em 1984, 1984 e 1986, respectivamente) têm um sumário similar, com as seguintes seções: Fatos; Temas;
4. Desde os anos 1970 o Iphan passava por uma série de mudanças, cuja análise não caberia no escopo deste artigo. Para um aprofundamento acerca do contexto dessa década, ver o dossiê sobre os 40 anos do Programa Cidades Históricas organizado por Flávia Brito do Nascimento e Paulo Garcez Marins para os Anais do Museu Paulista (2016). Sobre Aloísio Magalhães e o Centro Nacional de Referência Cultural (CNRC), ver Lavinas (2014) e Fonseca (1997, 2003). A incorporação do CNRC trouxe para o Iphan a equipe de comunicação. Sobre esse assunto, ver Dias (2012).

5. Entre as inúmeras instituições vinculadas à PróMemória, além do Iphan, estavam o Museu Histórico Nacional, o Museu da Inconfidência, o Museu Nacional de Belas Artes, o Museu Imperial, o Museu da República, a Biblioteca Nacional, a Cinemateca Brasileira, entre outras. Cf. Reale (2012); Calabre (2009). Ao longo da década de 1980, o Iphan tornou-se Secretaria do Patrimônio Histórico e Artístico Nacional e também Subsecretaria, passando a ser chamado de Sphan.

6. Sobre a trajetória do Boletim Sphan/Pró-Memória, ver Dias (op. cit.).

7. Para conhecer a trajetória da Revista do Patrimônio Histórico e Artístico Nacional, criada em 1937, ver Oliveira (2018) e Thompson et al. (2012). 
8. Escrevem nesses números renomados intelectuais, dentre os quais Aziz Ab'Saber, Sergio Miceli, Ulpiano Bezerra de Meneses, Silvio Tendler, Celso Furtado, Gabriel Cohn, Leandro Konder, Octavio Ianni e Roberto DaMatta. Cf. Revista do Patrimônio Histórico e Artístico Nacional (1984a, 1984b, 1986, 1987).

9. Nos dezoito números anteriores, a Revista do Patrimônio tinha o formato de uma coletânea especializada de artigos sobre o patrimônio histórico e artístico brasileiro. Sobre o assunto, ver Thompson et al. (op. cit.).

10. Cf. Chuva (2017b).

11. Velho (1984, 1986).

12. Id. (1986, p. 50)

13. Id. (1984, p. 38)

14. Id. (1986, p. 50).
Documento; Ideias; Projetos; e Ensaios. A seção Temas, especialmente, reuniu renomados intelectuais, de áreas diversificadas, que atuavam naquele momento nas trincheiras universitárias em defesa da democracia, bem como especialistas da própria instituição. O número 22, de 1987, apresentava mesas-redondas que reproduziam debates públicos organizados pela instituição sobre assuntos da ordem do dia, como núcleos urbanos/entorno; conservação/restauração; patrimônio natural; e patrimônio documental. ${ }^{8}$ Temas relacionados ao papel do Estado na cultura, às identidades dos bairros e à diversidade cultural nas cidades brasileiras, que explicitam a natureza política do patrimônio, passaram a fazer parte do repertório da nova série. ${ }^{9}$ É possível perceber que a democratização da sociedade brasileira, das políticas de patrimônio e das ações institucionais era pano de fundo que atravessava todos os debates.

Nesse novo formato, buscava-se manter o perfil especializado da Revista do Patrimônio, adotando, contudo, uma linguagem mais acessível e apresentando temas coetâneos e relacionados com questões sociais e políticas que envolviam a problemática da preservação cultural. Com essas medidas, o mundo institucional do patrimônio expunha tensões presentes na relação entre a Sphan/PróMemória e a sociedade, como também no interior da agência, envolvendo-a nos debates que a inseriam na arena de lutas pela redemocratização do país. ${ }^{10}$

Tais medidas são importantes indícios da renovação das práticas institucionais da então Sphan/PróMemória, dando maior transparência à natureza política do debate em torno do fazer patrimônio. Essa virada é crucial para uma instituição cuja autoimagem se pautava exclusivamente no discurso técnico especializado. Sem abrir mão do especialista, os debates demonstravam que a temática do patrimônio não estava apartada da vida social e política do país. Em outros termos, a linha da Revista do Patrimônio assumia abertamente que toda e qualquer política pública de interesse social, dentro do Estado democrático de direito, se faz no diálogo entre técnica e política.

O antropólogo Gilberto Velho na época ocupava a cadeira do Conselho Consultivo do Iphan reservada à representação do Museu Nacional e escreveu dois artigos na Revista do Patrimônio, mostrando alguns dos pontos que pautavam as lutas naquele momento. " Nesses textos, Velho estava atento à "conjuntura histórica", em um "contexto de mudança social", nas suas palavras, e projetava: "Em sociedades pluralistas e democráticas há que se buscar sempre o delicado equilíbrio entre diferentes projetos e valores". ${ }^{12} \bigcirc$ termo "heterogeneidade" aparece nos dois artigos, referindo-se à sociedade civil ${ }^{13}$ e à necessidade de serem legitimados os "símbolos materiais e imateriais dessa heterogeneidade". ${ }^{14}$ 
Nesse contexto de redemocratização do país e renovação institucional, a Sphan foi também responsável por tombamentos significativos relacionados ao reconhecimento, por meio da proteção de bens representativos, da participação dos negros na construção da nação. Ocorreram dois tombamentos tidos como emblemáticos pela historiografia do campo: do Terreiro da Casa Branca (llê Axé Iyá Nassô Oká), de Salvador, em 1984; e da Serra da Barriga, local dos vestígios do Quilombo dos Palmares, em 1986, em Alagoas. Não vamos nos deter no relato desses casos, já citados em diversos trabalhos. ${ }^{15}$ Nossa intenção é refletir sobre a noção de valor histórico que foi acionada nesses dois tombamentos com o sentido de valor documental, relativo ao passado e associado àquilo que é antigo.

Essa compreensão de valor histórico difere dos sentidos que foram estabelecidos na prática institucional nas primeiras décadas de atuação do Iphan - quando o valor histórico era acionado como um valor secundário, atribuído aos bens que, segundo a leitura da época, não guardavam autenticidade plenamente ou não representavam as origens genuínas da nação. ${ }^{16}$ Nos anos 1980, verificamos uma nova dimensão do valor histórico, que passava a ser atribuído a bens culturais por serem vestígios materiais que documentam eventos passados, tal como já foi abordado por Flávia Nascimento e Márcia Sant'Anna. ${ }^{17}$

Neste artigo, o que pretendo apontar na ideia de valor histórico ou documental, disseminada em várias ações do lphan (dos tombamentos aos inventários urbanos), é a linearidade da noção de tempo que está no cerne dessa concepção. Nela o passado permanece fixo e precede o presente, conforme o regime de historicidade que concebe o passado como magistra vitae; ${ }^{18}$ nessa direção, ruma-se para o presente e também para um futuro comum, produzido pela ação civilizadora da educação. Como diria Darcy Ribeiro, a democratização da própria educação, como da cultura em geral, seria a via para superar o atraso, bem como para construir uma sociedade democrática. ${ }^{19}$ Nessa perspectiva, o passado escravista deveria, sim, ser lembrado para jamais ser repetido.

Segundo François Hartog, ${ }^{20}$ um novo regime de historicidade, o presentismo, se delineia nos anos 1980 após a queda do Muro de Berlim. Nele, passado e futuro transportam-se para o presente, onipresente, onde se vive entre a amnésia e o desejo de lembrar. Como bem afirmou Paul Ricoeur, o passado pode ser muito mais indeterminado que o futuro. ${ }^{21}$ Dentro desse regime emergente, vemos um novo paradigma se configurar no campo do patrimônio.

A concepção linear de tempo impôs uma barreira para a compreensão da realidade presente como constituinte/formadora do patrimônio, isto é, como fruto de passados presentes, tal como trabalhado por Hebe Mattos, Keila Grinberg e
15. Sobre a patrimonialização do Terreiro da Casa Branca, ver Gilberto Velho (2006), referência primeira sobre o assunto; e, sobre a Serra da Barriga, ver Funari (2001).

16. Para aprofundar a ideia de valor histórico nas práticas do Iphan, ver Márcia Chuva (2009).

17. Nascimento (2016); Sant'Anna (2014).

18. Cf. Hartog (2013).

19. Ribeiro (1975).

20. Hartog (2006).

21. Ricoeur (2007) 
22. Mattos; Grinberg; Abreu (2018).

23. Essa ideia, que será desenvolvida ao longo do texto, tomou como ponto de partida o debate proposto por Paulo César Garcez Marins (2016), do qual incorporei a expressão "paradigma moderno".

24. Somente na gestão do Ministério da Cultura de Gilberto Gil (2003-2008) é que veríamos a implantação efetiva de um programa de ações nesse sentido. Sobre o assunto, ver tese de Marcelo Cardoso de Paiva (2019).

25. Criado em 1975, o Inepac buscou novas tipologias de bens, se comparadas à prática do órgão federal, mantendo, contudo, o olhar estético estilístico sobre a arquitetura, como analisado por Lia Motta (2000).
Martha Abreu. ${ }^{22}$ Para as autoras, esses são passados que não passam e que atingem diretamente as vidas no presente, e sobre eles não cabem leituras nostálgicas. Nessa reflexão, no bojo do presentismo, vimos ser delineado um novo paradigma do patrimônio como direito, como direito à presença, como reparação.

Desse modo, à construção do argumento de valor não foi atrelada a complexidade da vida naqueles locais no presente. Isto é, questões apontadas nos processos de tombamento do Terreiro da Casa Branca e da Serra da Barriga - fundiárias ou relacionadas à posse da terra e à favelização das áreas - foram percebidas como problemas que deveriam ser superados para que a patrimonialização se concretizasse plenamente, mantendo-se, assim, atrelados ao paradigma moderno ${ }^{23}$ do tempo linear.

Vale dizer que os dois casos - embora não configurassem, no âmbito da agência federal de patrimônio, diretrizes estratégicas de um novo programa de ações ${ }^{24}$ - foram emblemáticos, com efeitos materiais e simbólicos no campo do patrimônio, pois respondiam a demandas de grupos organizados da sociedade civil e foram impulsionados pela ressonância que teve, dentro da instituição, a ação de alguns de seus agentes que aderiram às pautas desses grupos.

No Rio de Janeiro, como veremos a seguir, as ações de patrimonialização da herança negra integraram, de fato, um programa estratégico com ação política mais orgânica e ampla. No contexto de uma abertura políitica lenta, gradual e controlada, em curso desde a Lei da Anistia, de 1979, ocorreram as eleições para os governos estaduais, em 1982, e para as prefeituras das capitais dos estados, em 1985. Foi quando o Rio de Janeiro elegeu Leonel Brizola, o trabalhista histórico gaúcho, como governador do estado. Para a prefeitura da capital, foi eleito Roberto Saturnino Braga. Configurou-se então um quadro político excepcional, se comparado com quaisquer conjunturas anteriores ou posteriores, marcado pela trajetória de luta pela democracia e contra a ditadura militar de ambos os dirigentes eleitos. Nesse cenário político de transição, o novo Partido Democrático Trabalhista (PDT), sob a liderança de Leonel Brizola, almejava voos mais altos para a esfera de poder federal.

Esse quadro alcançou a política estadual de patrimônio do Rio de Janeiro através do Inepac, sob a direção de ĺtalo Campofiorito, que investiu numa atuação distinta em relação ao órgão federal. Nessa vertente inovadora, o foco na herança negra e em zonas populares da cidade configuraria uma importante ação do órgão, marcando sua trajetória e memória institucional. ${ }^{25}$

Como outros temas que ganharam novas leituras ou se tornaram objeto de investigação acadêmica a partir do processo de redemocratização dos anos 
1980, as políticas de patrimônio tornavam-se tema de interesse das ciências sociais a partir dos anos 1990. ${ }^{26}$

Mariza Soares inaugurou uma reflexão acerca do tema específico da patrimonialização da herança negra no Rio de Janeiro em artigo publicado em 1999, articulando a renovação historiográfica da temática da escravidão com as novas reflexões sobre memória e patrimônio. Soares enfatizava o esforço de monumentalização da negritude que caracterizou o governo de Leonel Brizola e o papel desempenhado nesse processo por Darcy Ribeiro - vice-governador e secretário de Ciência, Cultura e Tecnologia que, na ocasião do tombamento da Pedra do Sal, teria conseguido "dar ao berço do samba o caráter de uma trincheira da resistência negra" ${ }^{27}$ Essa medida estava associada a outras, tomadas na mesma direção, como a construção do Sambódromo, do Monumento a Zumbi e da Escola Tia Ciata, localizadas na Praça Onze, área abrangida pela antiga Pequena África. ${ }^{28}$

artigo de Eucanaã Ferraz, publicado em 1997, que trata do tombamento da Pedra do Sal pelo Inepac também é uma importante referência para nossa discussão. Afirmava ele que tal medida ancorava-se na certeza de que a africanidade carioca que existira outrora, de modo intenso e pleno de sentidos, tornava-se patrimônio como prova documental dessa história, preservando com o tombamento um dos seus marcos físicos. ${ }^{29}$

A seguir veremos como, estrategicamente, a consagração da herança negra no Rio de Janeiro nos anos 1980 fazia parte de um projeto político de poder dentro do novo contexto democrático brasileiro. Depois analisaremos as duas ações de patrimônio e memória implementadas naquele contexto que, segundo Soares e Ferraz, voltaram-se para a afirmação da negritude na cidade negra imaginada por Darcy Ribeiro. ${ }^{30}$

\section{Projeto político nacional em disputa: a data de 20 de novembro como estratégia de luta}

Uma pista interessante para compreendermos as disputas efetivamente em cena e o seu caráter nacional refere-se à data de 20 de novembro - Dia Nacional da Consciência Negra -, escolhida como referência para celebrar os ritos e comemorações, que veremos mais adiante, da inauguração do Monumento a Zumbi e do tombamento da Pedra do Sal, levando-nos a refletir
26. Cf. Chuva (2014)

27. Soares (1999, p. 126).

28. "Pequena África" foi a denominação dada pelo jornalista Heitor dos Prazeres, em 1922, para uma vasta área na região portuária e central do Rio de Janeiro que concentrava afrodescendentes no pós-abolição. Nos anos 1940, a região foi cortada com a abertura da Avenida Presidente Vargas.

29. Ferraz (1997).

30. Soares, op. cit.; Ferraz, op. cit. 
31. Ata... (1985).

\section{Ibid.}

33. A Fundação Cultural Palmares foi criada pela Constituição Federal brasileira, em 1988, como agência pública para promover políticas inclusivas e reparadoras e lutar contra o racismo institucional existente no país.

34. Cf. Lara (2020).

35. Brasil (2011). sobre as diversas estratégias conectadas de construção e atualização de memórias e consagração com vistas a uma projeção nacional.

Essa aparente coincidência não se limita às iniciativas estaduais. A reunião do Conselho Consultivo da Sphan que decidiu pelo tombamento da Serra da Barriga foi realizada em 18 de novembro de 1985, com referência explícita em sua ata à proximidade do 20 de novembro. ${ }^{31}$ Esse processo foi aberto por abaixoassinado com mais de mil assinaturas. Em seu parecer, a arqueóloga Maria Beltrão, conselheira relatora desse caso, afirmava tratar-se de "local de resistência do grupo negro, lugar fundador, sonho de uma república negra." Seu parecer foi então aprovado por unanimidade.

O presidente do Conselho Consultivo do Patrimônio Histórico e Artístico Nacional, Angelo Oswaldo de Araújo Santos, ainda destacou na referida reunião - "forte simbolismo de que se reveste a Serra da Barriga, cujo significado se acentua no próximo dia 20, aniversário da morte de Zumbi, digo, data escolhida como Dia Nacional da Consciência Negra". 32 Diferentemente dos dias atuais, em que os representantes do governo que ocupam postos na Fundação Cultural Palmares ${ }^{33}$ promovem uma série de ações para esvaziar os sentidos de luta, resistência e reparação do dia 20 de novembro, ${ }^{34}$ nos anos 1980 essa data era requerida por diferentes setores sociais engajados no processo de redemocratização do país e na luta a ele associada contra o racismo institucional, a favor dos direitos culturais e da reparação dos efeitos do pós-abolição no Brasil. Apontada por historiadores, em 1971, como dia da morte do herói Zumbi dos Palmares, essa data vinha sendo consagrada desde os anos 1970 como signo da luta negra no Brasil, motivando membros do Movimento Negro Unificado contra a Discriminação Racial, em congresso realizado em 1978, a eleger a figura de Zumbi como símbolo da luta e resistência dos negros escravizados no Brasil, bem como da luta pelos direitos que seus descendentes reivindicam. A data foi incluída como efeméride no calendário escolar em 2003 e se tornou Dia Nacional da Consciência Negra em 2011.35 O projeto para tornar-se feriado nacional, contudo, tramita há alguns anos sem solução. Por sua vez, muitas cidades e cinco estados já decretaram o 20 de novembro como feriado.

Há uma série de datas comemorativas no Brasil e, ao analisar os feriados nacionais, verificamos a presença de datas católicas, datas cívicas internacionais e datas cívicas nacionais históricas. Nesse conjunto de comemorações cívicas inclui-se o 21 de abril, dia da morte de Tiradentes, que é a única data relativa a um personagem da história do Brasil tornado herói nacional. Foi a expectativa democrática dos anos 1980 que deu espaço para a constituição de um novo herói brasileiro e para ampliar o espectro da imaginação nacional sobre os excluídos. 
Como trabalhado por José Murilo de Carvalho, em qualquer tipo de poder os heróis são necessários para representar uma imagem da nação. ${ }^{36}$

$\bigcirc$ dia 20 de novembro celebra a figura de Zumbi dos Palmares, alçando-o, como Tiradentes, à categoria de herói nacional, considerado mártir. $\bigcirc$ projeto de lei para tornar a data feriado nacional aguarda votação, há alguns anos, no Congresso Nacional.

Desse modo, o dia 21 de abril permanece sendo o único feriado nacional em homenagem a um personagem da história do Brasil. Não faltam referências de estudos historiográficos que apontam os processos de construção do herói Tiradentes, bem como a reprodução da história na qual ele se tornou mártir, sendo então reconhecido amplamente pelos brasileiros que tenham passado pelo ensino escolar fundamental. Minas Gerais protagoniza esse fenômeno histórico e o processo de invenção do herói. Eventos rituais posteriores de alto valor simbólico para o fortalecimento da ideia de nação ocorreram no dia 21 de abril, tais como a inauguração de Brasília, em 1960, ou, no contexto da nossa análise, a morte de Tancredo Neves, em 1985, que casualmente acabou por atualizar as referências do mártir, envolvendo aquele dramático momento numa mística nacional.

A escolha dessas datas constitui um cálculo político assentado na ressonância do herói objetivado que, numa dinâmica de mão dupla, também fortalece sua capacidade de alcançar um mundo que ultrapassa seus próprios limites, por evocar "as forças culturais complexas e dinâmicas das quais emergiu" e das quais é uma metáfora, como tratou Greenblatt. ${ }^{37}$ Vimos falando de uma arena de lutas, com táticas e estratégias; não se trata, portanto, de um "pano de fundo estável e pré-fabricado", mas de "uma densa rede de forças sociais em evolução e muitas vezes em conflito". ${ }^{8}$

Há décadas a legitimidade, o reconhecimento e a ressonância do 20 de novembro como Dia da Consciência Negra têm sido construídos, embora ainda hoje haja resistências à sua transformação em feriado nacional. Isso é verificável no contexto político distópico que o Brasil vive em 2020, com um governo de extrema direita que chegou ao poder por eleição direta. Esse dia tornou-se um dos focos de ataque da política fascista, demonstrando não somente a força da data, como também a importância dos símbolos - trata-se de uma guerra de memórias e de narrativas na qual esse governo tem investido bastante. Muito se enganam aqueles que pensam tratar-se de uma luta menor, sem efeitos concretos na vida dos brasileiros, pois dela redundam políticas públicas de memória, patrimônio, educação e de muitos outros setores, como saúde e habitação, capazes de apagar as demandas daqueles que são representados por ela. ${ }^{39}$ Negando-se a herança africana de resistência, negam-se também seus efeitos ainda persistentes e, desse modo, aniquila-se a necessidade de quaisquer políticas de inclusão e reparação
36. Carvalho (1990).

37. Greenblatt (1991, p. 250).

38. Ibid., p. 251.

39. Vale lembrar que a luta está em pleno curso, havendo setores na sociedade não somente contrários à aprovação do feriado nacional, mas também a favor da revogação do feriado decretado em várias cidades. Cf. Pai Rodney (2017). 
40. Há farta bibliografia sobre o assunto, do qual se pode ter um bom panorama no artigo de Grinberg (2019). pelo Estado. O negacionismo verificado hoje vai de encontro a uma robusta produção acadêmica, resultante do projeto de escrita de uma história do Brasil em que se incluíssem a população negra e o tema da escravidão, que teve seu momento de virada para uma produção mais crítica justamente nos anos 1980, quando a produção historiográfica se expandiu significativamente. ${ }^{40}$

A realização das celebrações de 20 de novembro aqui analisadas, portanto, deixam transparecer não apenas o trabalho de consagração de Zumbi dos Palmares como herói na história brasileira, mas principalmente a disputa pelo controle da narrativa a respeito de quem o herói representaria, com quem se identificaria e para quem capitalizaria politicamente. Nos anos 1980, diferentes grupos disputavam esse herói, pois tomavam a data para suas diversas celebrações. Pelas evidências apontadas, vimos que o poder público estadual estava interessado na promoção de ações emblemáticas nesse sentido, participando - por meio das políticas de memória e patrimônio - da construção de uma nova narrativa sobre a história do Brasil. A participação de políticos do Rio de Janeiro no processo de invenção de um novo herói nacional com origem em Alagoas serviria também, na via de mão dupla referida anteriormente, para projetar esses atores nas eleições para a Presidência da República, realizadas em 1989.

A produção de uma identificação de Leonel Brizola com o 20 de novembro faria, portanto, um importante contraponto com aquela imagem construída que identificou os políticos mineiros Juscelino Kubitschek e Tancredo Neves com o consagrado herói Tiradentes, cuja idealização enquanto mártir libertador da nação tantas vezes foi evocada.

\section{DUAS AÇÕES DE AFIRMAÇÃO DA NEGRITUDE}

\section{Monumento a Zumbi dos Palmares: redemocratização e disputas sobre os espaços da cidade}

A construção do Monumento a Zumbi em 1986 resultou de iniciativas de setores do movimento negro do Rio de Janeiro junto ao governo estadual, que assumiu o projeto, trazendo para a esfera do poder público, de forma inovadora, o debate sobre a cidade negra de Darcy Ribeiro e a herança negra na cultura carioca.

Posteriormente, representantes do movimento negro tomaram para si a tarefa de cuidar para que o monumento permanecesse na cena políitica da cidade, tendo em 
vista que a temática perderia o protagonismo nos governos subsequentes, estaduais ou municipais. Quem queria lembrar que o Rio era uma cidade negra? Para a manutenção persistente dessa memória, representantes do movimento não deixaram sem resposta ações que visavam minimizar ou apagar a figura de Zumbi como herói, tais como as violentas pichações de suásticas feitas no monumento (Figura 1).

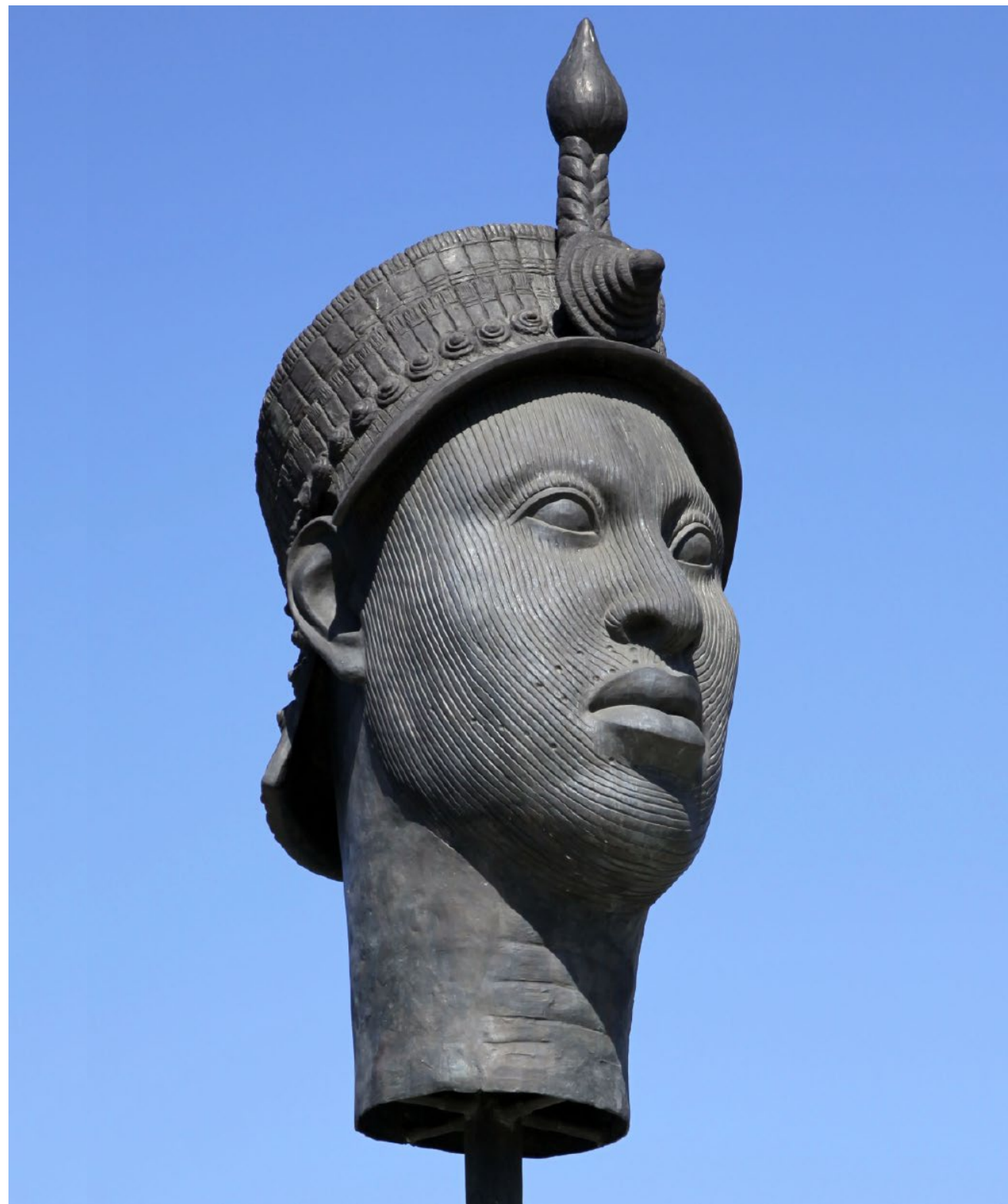

Figura 1 - Monumento a Zumbi, no Rio de Janeiro. Foto: Halley Pacheco de Oliveira, $2012 .{ }^{41}$ Fonte: <https://creativecommons.org/licenses/by-sa/3.0 > / <https://upload.wikimedia.org/wikipedia/ commons/d/d9/Zumbi_dos_Palmares.jpg $>$.
41. Disponível em: <https:// bit.ly/32bvdai $>$. 
42. O Grito dos/as Excluídos/as são manifestações populares que ocorrem em todo o Brasil na semana de comemoração da independência brasileira, desde 1995, com o objetivo de denunciar os mecanismos sociais de exclusão e propor caminhos alternativos para a sociedade, tendo origem em ações da Conferência Nacional dos Bispos do Brasil (CNBB) nos anos 1993 e 1994. Cf. <https:// bit.ly/3oU2O2p>.

43. Cf. Silva (2000).

44. Não analisaremos o movimento negro, cuja diversidade de grupos, ações e ideias não está no escopo deste artigo. Apontamos algumas iniciativas do PDT, no primeiro governo de Leonel Brizola, de aproximação com a pauta do movimento e de valorização da cultura negra, tal como capturamos em fragmentos recolhidos na imprensa da época, a partir de buscas dirigidas especificamente à Pedra do Sal e ao Monumento a Zumbi na hemeroteca da Biblioteca Nacional. Usaremos, portanto, o termo genérico "movimento negro" e citaremos alguns de seus agentes conforme tenham aparecido no material empírico trabalhado.

45. Soares, op. cit.

46. Cf. Luther... (1986). Segundo Soares (op. cit.), José Miguel não atuava junto ao movimento negro até tornar-se deputado.

47. Cf. José... (1983).

48. Cf. Aprovado... (1983).
Curiosamente, essas agressões acabam servindo para atualizar a memória, reforçando a resistência. São representantes do movimento negro que ocupam espaço na imprensa para demonstrar seu repúdio às pichações recorrentemente feitas no monumento. A eles coube também a invenção do rito da sua lavagem, sempre no dia 20 de novembro. Além disso, ali se encerram inúmeras manifestações e passeatas, tal como o Grito dos/as Excluídos/as, que acontece há 25 anos no feriado da Independência do Brasil, dia 7 de setembro. ${ }^{42}$

No contexto de restabelecimento da democracia no país, a modernização autoritária foi posta em xeque por forças políiticas represadas pela ditadura militar, e a crise instaurada abriv espaço para severas disputas entre projetos políticos variados. ${ }^{43}$ O PDT de Darcy e Brizola, que representava um dos caminhos apontados naquela disputa, fez alianças com representantes do movimento negro do Rio de Janeiro e teve no deputado José Miguel um importante articulador junto ao Poder Legislativo estadual. ${ }^{44}$

Mariza Soares, ao analisar a construção do Monumento a Zumbi, optou por trabalhar com periódicos da grande imprensa, apontando o que chamou de "discurso da negritude". Pela ótica da imprensa, o governo do estado e o movimento negro compartilhavam esse "discurso da negritude", embora não houvesse homogeneidade entre ambos, tampouco uma fala única do movimento. A autora afirma que entre 1982 e 1986 ocorreu um progressivo estreitamento da relação entre o governo do estado e o movimento negro. ${ }^{45}$

Ao buscar na imprensa da época notícias sobre a construção do monumento, encontramos uma curiosa polêmica em torno do local onde deveria ser instalado o monumento de celebração a Zumbi dos Palmares na cidade do Rio de Janeiro. Vimos também em diferentes jornais uma associação direta entre ele e o contexto político eleitoral da época.

Foi o deputado José Miguel, apresentado no Jornal dos Sports como líder do Movimento Negro no Rio de Janeiro, ${ }^{46}$ quem representou na Assembleia Legislativa o projeto de criação do Monumento a Zumbi dos Palmares e defendeu sua alocação no Aterro do Flamengo. Segundo reportagem do mesmo periódico, o deputado afirmava que Zumbi havia sido o primeiro socialista em terras brasileiras. ${ }^{47} \mathrm{~A}$ criação do monumento pela Assembleia Legislativa fluminense foi aprovada em 30 de outubro de 1983, ainda sem localização definida. ${ }^{48} \bigcirc$ debate a esse respeito persistiria alguns anos: a imprensa noticiava como desejo de Darcy Ribeiro vê-lo construído no Aterro do Flamengo, entre o Museu de Arte Moderna e o Monumento Nacional aos Mortos da Segunda Guerra Mundial, também conhecido como Monumento aos Pracinhas, numa paisagem simbólica e exuberante da cidade moderna e burguesa. Mariza Soares, contudo, desconsidera essa ideia, afirmando que, ao tomar o projeto 
para si, Darcy já projetava transportá-lo para a Avenida Presidente Vargas. ${ }^{49}$ Penso que esse ponto pode ser melhor compreendido se agregarmos referências específicas do debate do campo do patrimônio.

Para refletir, então, sobre as disputas em jogo nessas negociações, me perguntei o que estaria reservado para quem na cidade do Rio de Janeiro: qual seria - lugar da representação da cidade negra? Tudo leva a crer que seu lugar no tempo seria o passado e, no espaço, seu lugar seria aquele onde outrora havia ruas e construções do centro antigo do Rio, cenário desse passado. $\bigcirc$ Aterro do Flamengo (voltaremos a ele adiante) simbolizaria a cidade moderna e, talvez por isso, não parecia compatível com a celebração da africanidade e da resistência que a memória de Zumbi evocava. O comprometimento dessa escolha fica mais claro ao pensarmos que o lugar produz efeitos simbólicos que se materializam em distinções e, por isso mesmo, é acirradamente disputado. ${ }^{50}$ Desse modo, a cidade negra não alcançaria a cidade moderna nem no tempo nem no espaço. Campofiorito, ao se posicionar contrariamente à alocação do monumento no Aterro do Flamengo, argumentava que sua localização no centro da Avenida Presidente Vargas, onde de fato se concretizaria, the parecia mais honrada por situar-se na antiga Pequena África. $\bigcirc$ arquiteto urbanista explicava, então, que essa grande área foi desestruturada pela abertura da avenida. Portanto, para ele, nada mais simbólico para religar a Pequena África, dilacerada, do que a instalação do monumento no meio dessa via na qual milhares de pessoas transitavam diariamente, por ser o principal meio de acesso da Zona Norte ao Centro. Nesse momento, sua fala fica perfeitamente afinada com o "discurso da negritude", como apontado por Soares. ${ }^{51}$

Dessa peleja, gostaria de destacar dois aspectos: o primeiro deles refere-se à crença de que na cidade moderna, simbolizada pelo Aterro do Flamengo, construído pelos famosos arquitetos modernistas da escola carioca là qual Campofiorito se vinculava) e tombado pelo Iphan, ${ }^{52}$ não caberia o passado escravista que fundara a nação na diáspora. Esse passado não poderia ser esquecido, para que não se repetisse, mas as referências a ele deveriam mantê-lo no passado. Ali, na cidade moderna, projetava-se o futuro e, nesse futuro, superado o atraso por meio da educação, as diferenças raciais não espelhariam mais um problema a ser vencido, conforme idealizava Darcy Ribeiro. ${ }^{53} \bigcirc$ outro aspecto que destaco é que as tensões mostravam não haver uma narrativa dominante estabilizada. As disputas continuariam acirradas e com novas configurações naquela intensa década de 1980 - pelo menos entre 1986 e 1989 -, na sequência de fatos que se desenrolavam na macropolítica em torno da promulgação da nova Constituição brasileira, em 1988, e da instituição de eleições diretas no Brasil.
49. Soares, op. cit.

50. Análise inspirada nas reflexões sobre os efeitos de lugar de Pierre Bourdieu (1997)

51. Soares, op. cit. 52. Cf. Chuva (2017b). 53. Cf. Ribeiro; Matias (2006). 
54. Cf. Brizola... (1986).

55. Instituto Estadual do Patrimônio Cultural (1984).
A inauguração do Monumento a Zumbi ocorreu em 9 de novembro, tendo em vista que as eleições seriam realizadas no dia 15, e pretendia-se que sua festa fosse a cartada final da campanha. Evidentemente, as referências ao dia 20 de novembro foram explícitas e amplamente utilizadas. ${ }^{54} \mathrm{Com}$ uma grande festa amplamente noticiada na imprensa, o monumento tornou-se um trunfo da campanha eleitoral de Darcy Ribeiro, lançado como candidato do PDT ao governo estadual. Essa campanha fazia parte de um projeto nacional mais amplo, que perdeu sua força com a derrota de Darcy nessa disputa, seguida da derrota de Brizola nas superconcorridas eleições presidenciais de 1989.

\section{O tombamento da Pedra do Sal pelo Inepac: um caráter passadista}

A Pedra do Sal é descrita no processo de tombamento, de 1984, como "testemunho cultural mais que secular da africanidade brasileira, espaço ritual consagrado e o mais antigo monumento vinculado à história do samba carioca". Ali, diz o documento, "estão inscritas as raízes do nosso samba". ${ }^{55} \mathrm{O}$ principal critério em vista refere-se à ancianidade atribuída ao monumento, ideia geralmente associada, no campo do patrimônio, ao valor histórico (Figura 2).

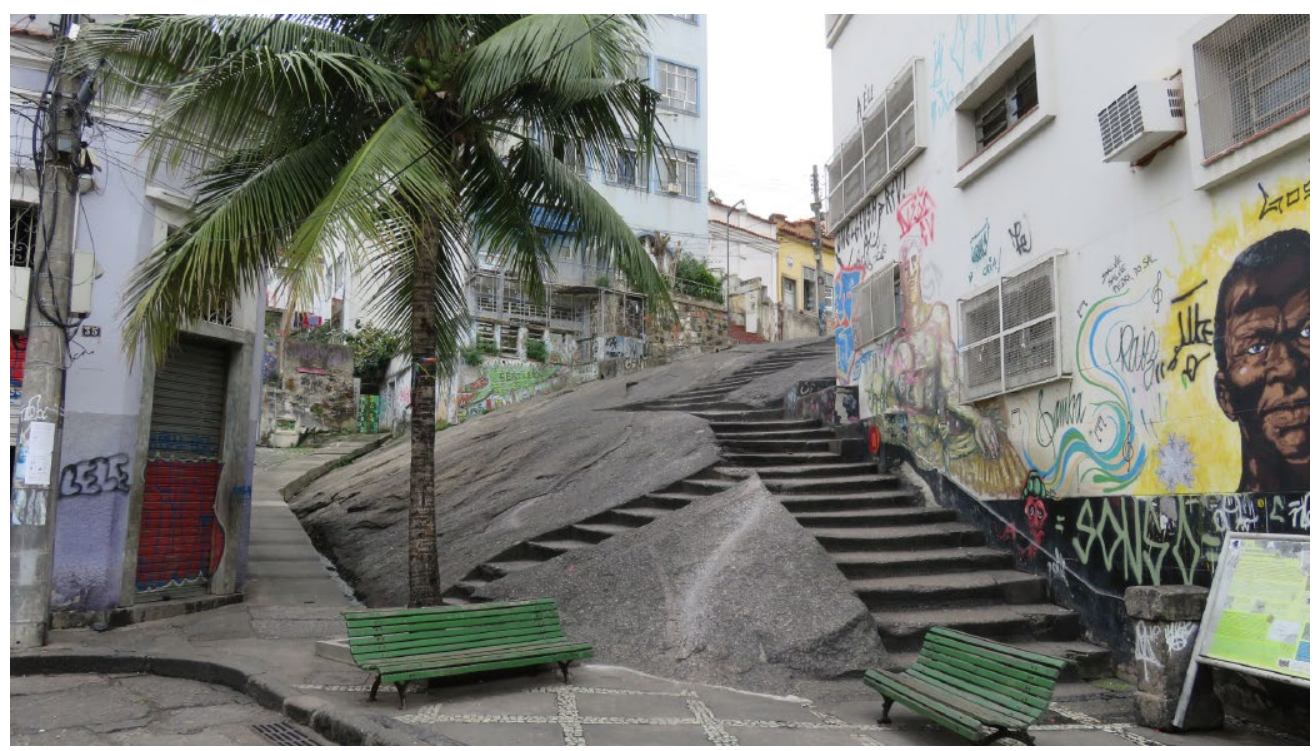

Figura 2 - Pedra do Sal, Rio de Janeiro. Foto: José Pessoa, 2017. Fonte: Cedida pelo autor. 
Para Eucanaã Ferraz, o tombamento da Pedra do Sal não pressupunha a continuidade no tempo de uma identidade negra, que exigiria uma homogeneidade idealizada, "como um corpo sem fissuras". ${ }^{56}$ Desse modo, se por um lado rompia com essencializações e com a ideia de identidade negra una para enfatizar sua pluralidade, por outro, reforçava a visão da herança africana carioca equacionada em algum lugar do passado, distante do tempo presente. Ferraz cita Ítalo Campofiorito:

De agora em diante, levanta-se uma nova hierarquia de valores no Morro da Conceição. Não são só os entornos do Palácio Episcopal, da Fortaleza da Conceição, da lgreja de São Francisco da Prainha - bens tombados por sua glória superior - que garantem o velho casario: de baixo pra cima, é o monumento negro que protege o resto. ${ }^{57}$

Refletindo sobre esse tombamento, Ferraz se pergunta: "o que é, como cidade, o Rio de Janeiro? A de Pereira Passos ou a de João da Baiana? As esquinas e armazéns da Gamboa ou os calçadões litorâneos? A trama de montanhas e casario das imagens de Marc Ferrez ou seus escombros, registrados pelas lentes de Malta?"58 Aqui também o valor histórico entra em cena para documentar o passado.

Era intenção dessa ação patrimonial o reconhecimento da Pedra do Sal como monumento, ao lado do Monumento a Zumbi dos Palmares, pois as duas ações traziam à lume a tradicional região da Pequena África como lugar histórico de efetiva representação e ocupação negra na cidade. Esse ato político tem uma força simbólica inaugural evidente.

Roberto Conduru retoma, em 2010, algumas reflexões sobre aquele contexto. Para o autor, a política estadual havia sido estratégica e diretiva, tendo o tombamento da Pedra do Sal integrado um conjunto de ações não isoladas, voltadas para o reconhecimento da herança negra e popular no Rio de Janeiro. Estamos em consonância com essa interpretação, sobre a qual o autor prossegue: "o poder público estadual reconstituía simbolicamente a Pequena África, que fora dizimada pelos processos excludentes de ocupação do território urbano pela especulação imobiliária". ${ }^{59}$ Quais os efeitos dessa reconstituição simbólica naquele contexto?

$\bigcirc$ historiador Joel Rufino dos Santos, que foi o relator do pedido de tombamento da Pedra do Sal no Inepac, afirmava que o samba e o candomblé vindo da Bahia descreviam a região. ${ }^{0}$ Sua ênfase está na construção da história excepcional do local, referindo-se a seus nomes, ocupações e usos no passado. Era esse passado extraordinário que daria ao bem o valor de patrimônio.

Ao buscar notícias na imprensa sobre esse processo, encontrei reportagens com depoimentos de moradores daquela zona que mostraram um olhar distinto,
56. Ferraz,op. cit., p. 337-338.

57. Campofiorito apud Ferraz, op. cit., p. 336. O texto citado por Ferraz é o parecer de tombamento elaborado por Ítalo Campofiorito, em 1984.

58. Ferraz, op. cit., p. 337.

59. Conduru (2010, p. 196).

60. Instituto Estadual do Patrimônio Cultural, op. cit. 
61. Cf. Cyntrão (1984, 1985); Santos (1984).

62. Cf. Perfeito (1985).

63. Na reportagem, há depoimentos do estivador Antonio dos Santos ferreira, de 61 anos, frequentador da região e do mesmo bar que frequentavam João da Baiana, Donga e Pixinguinha; e também de Leopoldo Martins, morador de 71 anos e trabalhador do Cais do Porto, que conheceu João da Baiana e foi diretor do Mauá Futebol Clube. Cf. Perfeito, op. cit.

64. Ibid.

65. Santos, op. cit.

66. A exemplo do Projeto Santo Cristo, Gamboa, Saúde (Sagas), realizado pelo órgão de patrimônio municipal na região desde os anos 1970, bem como de ações coordenadas no bairro da Saúde envolvendo os órgãos de patrimônio das três esferas governamentais. Cf. Moreira (2004); Faria (2016). não evidenciado na documentação do tombamento. A herança africana - dos tempos do cais, do tráfico e da escravidão - era acionada pelos residentes entrevistados de forma nostálgica, descolada das reivindicações por qualidade de vida e direito a moradia digna - temas defendidos pela Associação de Moradores do bairro da Saúde. ${ }^{61}$ De um modo ou de outro, o passado estava condenado a permanecer distante e desconectado das demandas práticas do presente. Entre os entrevistados, predominou a ideia de que na Pedra do Sal já não havia mais nada daquele passado memorável e de que os descendentes de escravizados já tinham morrido ou se mudado. 62 Tratava-se de um tempo remoto, apaziguado pela distância no tempo, domesticado pelas falas saudosistas sobre - local que um dia foi berço do samba e do candomblé. São entrevistados trabalhadores da estiva no porto, saudosos dos tempos de João da Baiana, Donga e Pixinguinha, e também do Mauá Futebol Clube. ${ }^{63}$ Predominava a ideia da Pedra como primeiro reduto negro da Saúde, ocupada por baianos do samba e do candomblé no início do século XX, sendo berço dos ranchos carnavalescos e local de desembarque do sal no Brasil Império.

O relato de dona Julia de Campos, portuguesa que ali chegou ainda criança, em 1936, indica um desconhecimento da história da cultura negra do lugar, mas contém queixas do abandono. ${ }^{64}$ Predomina em sua fala a reivindicação encabeçada pela Associação de Moradores da Saúde de que o bairro seja zona residencial, e não portuária, tendo em vista o abandono da Praça da Harmonia, a saída de antigos moradores e o fechamento das vendas e quitandas da região, que foi perdendo seu caráter residencial. Por mais organizados que tais movimentos populares se revelem, no bojo de suas reivindicações percebemos um fosso entre passado e presente. ${ }^{65}$

Vimos que o tombamento da Pedra do Sal detonou processos importantes de reconhecimento da herança negra naquela área da cidade; contudo, não inseriv esse ato no conjunto de ações voltadas para a preservação daquele local. De fato, uma série de iniciativas de patrimonialização vinha acontecendo na região, 66 sobre as quais não há menção nas narrativas de valor para a patrimonialização da Pedra do Sal. Isolada, quer no passado, quer dos seus vínculos com o bairro da Saúde, reforçava-se um lugar de excepcionalidade, condizente com o tradicional valor que fundara as práticas no campo do patrimônio.

Ao analisar um conjunto de ações emblemáticas dos anos 1980, refletimos sobre as conexões entre memória e patrimônio e sobre projetos de poder que estavam sendo construídos em âmbito nacional, diretamente conectados com o debate sobre a presença do negro na história do Brasil. Veremos a seguir que proporções esse debate tomou no Rio de Janeiro, nos anos 2000, em função das 
ações implementadas na cidade, considerando a possibilidade de novos paradigmas se delinearem no campo do patrimônio.

\section{A Pedra do Sal é um quilombo}

Em 2005, a Pedra do Sal foi reivindicada, junto com seu entorno, como marco simbólico de uma comunidade remanescente de quilombo, ${ }^{67}$ formada por moradores da região que se intitulam herdeiros e continuadores das tradições e da memória da presença negra no lugar. A narrativa do tombamento estadual foi por eles acionada: o local teria assistido à criação dos primeiros terreiros de candomblé da cidade e servido como ponto de encontro de compositores como Donga, João da Baiana e Pixinguinha, que se reuniam ali para cantar e fazer seus sambas. Rompia-se, desse modo, a fronteira do passado com o presente. Além da materialidade das pedras esculpidas pelos escravizados no século XIX, havia ali sujeitos conectados com esse passado, entrelaçados com as heranças do território, das práticas e das histórias do lugar.

As relações entre os quilombos e o campo do patrimônio estão postas desde a Constituição Federal de 1988.68 A regulamentação do artigo 68 do Ato das Disposições Transitórias Constitucionais (ADTC) ocorreu somente em 2003, por meio do Decreto $n^{\circ} 4.887$ que consagrou o quilombo como uma categoria do presente, não relativa a um passado distante e superado.

O valor histórico - até então apenas compreendido como relativo ao passado - foi acrescido de uma nova temporalidade: o presente. A partir daí um novo modo de pensar o patrimônio se delineia, vindo a subsidiar o que referimos como paradigma que funda o patrimônio como direito, como reparação. Se, em âmbito federal, essa questão tornou-se central em diversas situações durante a implantação das políticas de patrimônio imaterial, com o registro e o inventário, ${ }^{69}$ no Rio de Janeiro a luta pela declaração da Pedra do Sal como quilombo ancorou-se na sua patrimonialização como bem de natureza material, realizada nos anos 1980, conforme tratamos anteriormente.

O reconhecimento do Quilombo da Pedra do Sal foi formalizado em 2010 pela Fundação Cultural Palmares, que em seguida criou um grupo de trabalho para subsidiar a regularização da posse da terra junto ao Instituto Nacional de Colonização e Reforma Agrária (Incra) e as questões fundiárias que a conquista dessa titularidade pela comunidade quilombola trouxe. As
67. Hoje denominada Associação da Comunidade Remanescente do Quilombo da Pedra do Sal (Arqpedra).

68. Cf. Chuva (2017b).

69. Este foi o caso, por exemplo, do Jongo no Sudeste, que teve inventário de referências culturais e foi registrado no Livro Formas de Expressão em 2005. 
tensões e os conflitos, ainda sem solução plena, deram-se especialmente com a Venerável Ordem Terceira de São Francisco da Penitência, da lgreja Católica, que se apresenta como proprietária de inúmeros edifícios na região.

referido grupo de trabalho produziu um Relatório técnico de identificação e delimitação da comunidade remanescente do Quilombo de Pedra do Sal e contou com a participação das historiadoras Martha Abreu e Hebe Mattos. Elas afirmam que o Quilombo da Pedra do Sal surgiu das discussões sobre os usos do patrimônio cultural negro na zona portuária do Rio de Janeiro. ${ }^{70}$ Essa seria uma associação entre patrimônio e direitos que se inaugurava com sucesso naquele caso e subsidiaria várias reflexões sobre um novo paradigma para o campo do patrimônio.

No meu entendimento, com a criação do Quilombo da Pedra do Sal o tempo da Pequena África foi efetivamente atualizado, não mais se referindo à nostalgia de um tempo que não volta mais ou aos problemas a serem superados para o patrimônio poder fruir livremente. A Pedra do Sal, enfim, catalisa as dinâmicas culturais e históricas que instituem as memórias no tempo presente.

É na sutileza dessa virada para o presente que vimos se configurar um paradigma de patrimônio como direito e de reparação como possibilidade. Não nos referimos aqui à continuidade no tempo, como se buscássemos a genealogia dos ancestrais no território. Referimo-nos aos passados presentes que impõem lugares de invisibilidade para parcelas da população. Estas, por sua vez, têm enxergado nos processos de patrimonialização possibilidades para reivindicar e conquistar direitos à posse da terra, à memória e ao presente, como a reparação no caso das comunidades quilombolas.

\section{O Rio de Janeiro é duas vezes Patrimônio Mundial}

No processo de constituição do Quilombo da Pedra do Sal vislumbramos um novo paradigma de patrimônio como direito. Ações de patrimonialização subsequentes sobre a cidade tornaram-na duas vezes Patrimônio Mundial. Para compreender os modos como a herança negra representa (ou não) a cidade patrimonializada, analisamos os dossiês desses dois processos e encontramos perspectivas de patrimônio concorrentes, que convivem, disputam e transformam a cidade.

Em 2012, o título de Patrimônio Mundial foi concedido ao Rio de Janeiro, Paisagens Cariocas entre a Montanha e o Mar-título do dossiê encaminhado pelo Iphan à Unesco. ${ }^{71}$ Nele é protagonista a cidade plasticamente bela, esteticamente 
projetada por arquitetos modernistas ligados à escola carioca, cenário da imagem mundialmente famosa da Baía de Guanabara e do Pão de Açúcar. ${ }^{72}$ Simultaneamente, em 2011 , durante as obras da grande reforma do Porto Maravilha, ${ }^{73}$ apareciam a céu aberto os vestígios do Cais do Valongo, enterrado desde 1843 para construção do Cais da Imperatriz. Apenas cinco anos depois, em 2017, o Rio de Janeiro receberia novo título de Patrimônio Mundial. Agora era a vez do Sítio Arqueológico Cais do Valongo: no dossiê encaminhado pelo Iphan à Unesco, revelam-se os vestígios da cidade negra e do seu passado escravista, tratando-se de memória sensível, reparação e dor. ${ }^{74}$

O dossiê que fundamenta a candidatura que concedeu o título de Patrimônio Mundial ao Rio de Janeiro na categoria de Paisagem Cultural tem no Parque do Flamengo - aquele mesmo sugerido, sem sucesso, como local para o Monumento a Zumbi dos Palmares - uma peça-chave na argumentação da "autenticidade e integridade" da paisagem cultural do Rio de Janeiro. ${ }^{75} \bigcirc$ Parque é referido diversas vezes em função de seus atributos formais - paisagístico, natural, arquitetônico - e também por ter seu projeto assinado pelos arquitetos modernistas (da escola carioca) Affonso Reidy e Burle Marx. ${ }^{76}$ A expressão "o homem carioca", usada nesse dossiê para referir os moradores da cidade do Rio de Janeiro, confronta-se brutalmente com a diversidade ou heterogeneidade - para retomar a palavra de Gilberto Velho ${ }^{77}$ - daquilo que quer espelhar. Na imagem da cidade do Rio de Janeiro, aspectos plásticos, estéticos e paisagísticos prevaleceram.

Uma narrativa distinta se apresenta na argumentação que levou à inclusão do Sítio Arqueológico Cais do Valongo na lista do Patrimônio Mundial da Unesco: o dossiê encaminhado ao órgão pelo lphan busca analisar a região em continuidade, preenchendo os pontos vazios na sua história - na perspectiva da presença dos afrodescendentes. ${ }^{78}$ Pelo Cais do Valongo chegaram, no século XIX, mais de novecentos mil africanos, tendo sido o porto de maior entrada de negros escravizados nas Américas.

Percebe-se nesse dossiê, por um lado, a consistência do debate historiográfico, em que a temática da presença africana foi eficazmente colocada em perspectiva de longa duração, considerando nos vestígios materiais do antigo cais traços da escravidão e do tráfico e seus efeitos ainda no presente. Por outro lado, todo o percurso de políticas de patrimônio implementadas na área desde os anos 1980, que já abordamos parcialmente, não foi considerado, tampouco informações sobre a população local, para além dos envolvidos com o Quilombo da Pedra do Sal.

A leitura dos diferentes momentos de esvaziamento da região no âmbito da ação do patrimônio, inserindo o cais na trajetória das políticas ali implementadas, ou mesmo da falta delas, poderia ter sido um elo para compreender a região e suas
72. Cf. Chuva (2017a).

73. O Projeto Porto Maravilha foi um empreendimento da prefeitura do Rio de Janeiro, em parceria com os governos estadual e federal, com vistas à transformação da região portuária para o turismo, em função dos megaeventos que ali aconteceriam - as Olimpíadas, em 2016, e a Copa do Mundo no Brasil, em 2014 -, provocando uma brutal reestruturação urbana na área. Sobre o assunto, ver Faria (op. cit.).

74. Instituto do Patrimônio Histórico e Artístico Nacional (2016).

75. Lodi, op. cit.

76. Para maiores informações sobre a patrimonialização do Aterro do Flamengo, no Rio de Janeiro, ver artigo de Márcia Chuva (2017a), onde mais detidamente o assunto foi analisado. Sobre a escola carioca de arquitetura moderna, ver Marins (op. cit.).

77. Velho (1984, 1986).

78. Instituto do Patrimônio Histórico e Artístico Nacional (2016). 
79. A categoria de aglomerados subnormais surge em 1987 no IBGE. Em 2006, "o IBGE iniciou uma reflexão com o objetivo de ampliar seu conhecimento das características dos setores censitários classificados como aglomerados subnormais, áreas conhecidas ao longo do País por diversos nomes, como: favela, comunidade, grotão, vila, mocambo, entre outros" (Instituto Brasileiro de Geografia e Estatística, 2013, p. 9). populações no presente. O valor de excepcionalidade parece ter sido aqui novamente acionado. Seria o Cais do Valongo, nessa perspectiva, uma relíquia do passado?

Os breves comentários sobre os dois casos que levaram o Rio de Janeiro ao título de Patrimônio Mundial ao lado do Quilombo da Pedra do Sal tiveram o intuito de evidenciar tensões entre paradigmas, como se fundamentam seus discursos de valor, bem como as idas e vindas em suas dinâmicas de construção de legitimidade. Vimos, por meio deles, que dois paradigmas ordenam as ações e percepções que vigoram na atualidade e disputam posições no campo do patrimônio, aqui denominados de paradigma moderno e paradigma dos direitos.

\section{CONSIDERAÇÕES FINAIS}

Como dizer se a vontade de Darcy Ribeiro se cumpriu? Numa perspectiva, vimos que a cidade negra não cabe na cidade moderna, no presente. Àquela teria sido reservado o charmoso, decadente e nostálgico Rio das antigas ruas, dos sobrados, dos negros escravizados, do pós-abolição, das origens do samba e da capoeira. É o Rio cujos vestígios materiais se fazem presentes nas proximidades da Praça Mauá e da Praça Onze, partes de uma antiga Pequena África rompida pela modernidade da Avenida Presidente Vargas e religada pelo simbólico monumento nela instalado.

A população da cidade do Rio de Janeiro hoje gira em torno dos 6,7 milhões de habitantes, dos quais 55,4\% se autodeclaram negros ou pardos, ou seja, a maioria da população da cidade. Mas não bastam números objetivos para o Rio "ser uma cidade negra" no que compete à política de patrimônio. Há diferentes forças em jogo, e esse dado demográfico expressivo não parece estar representado nas imagens dominantes da cidade patrimonializada, nas quais a invisibilidade dessa imensa parcela negra da população, é patente e atual.

Na cidade do Rio de Janeiro, no metrô, nas barcas, no trem - os transportes de massa -, pode-se ver diariamente grupos de teatro e poesia atuando com uma fala de afirmação dessa identidade negra, associada a outras identidades, como a do pertencimento à favela e à periferia, que estão excluídas daquela imagem fantasiosa do "homem carioca". Os grupos mobilizam suas expressões como patrimônio, mas não furam os bloqueios que os mantêm como "periferia", como os que moram "longe" ou, ainda, conforme a categoria criada pelo Instituto Brasileiro de Geografia e Estatística (IBGE), os que moram em aglomerados subnormais ${ }^{79}$ - as favelas. 
Na formação escolar, estudam-se as reformas europeizantes na cidade do Rio de Janeiro, realizadas pelo prefeito Pereira Passos no início do século XX: são as reformas urbanas, o afastamento das populações para os subúrbios, a linha do trem, a Baixada, a Zona Oeste, num movimento contínuo que requereu sempre somas vultosas de recursos, com desmonte de morros e novos aterros, abertura de avenidas onde havia moradias populares, construção e demolição de viadutos e vias expressas para a cidade dos carros. Dificilmente, contudo, essas medidas, que têm uma surpreendente continuidade, são postas lado a lado em diacronia e tiradas da perspectiva isolada de eventos excepcionais para serem compreendidas como um padrão urbanístico excludente, voltado para os interesses diversos do capital.

Ao estudarmos tais processos que ocorrem incessantemente na cidade do Rio de Janeiro numa perspectiva radical, podemos pensá-los como estratégias de branqueamento da cidade moderna?

No meu entendimento, as narrativas de valor histórico tal como pensadas nos anos 1980 foram cruciais para a ampliação e diversificação da ação de preservação, como visto nos casos aqui citados, mas eram regidas pelo paradigma moderno do campo do patrimônio, coerente com o regime da história magistra vitae. Desse modo, a concepção linear de tempo impôs uma barreira para a compreensão da realidade presente como constituinte/formadora daquele patrimônio, isto é, como fruto de passados presentes - passados que não passam e atingem diretamente as vidas na atualidade. São passados que precisam ser reconhecidos na dimensão do trauma, no tempo presente, para serem superados pela via dos direitos e pela luta por reparação.

Os dois paradigmas que verificamos ao longo deste artigo tensionam o campo do patrimônio. No paradigma moderno, a preservação do patrimônio teria o papel de manter o passado no seu lugar para proteger a cidade moderna do contágio de um tempo que se deve lembrar para não repetir. Assenta-se, assim, numa perspectiva linear do tempo. Para isso, as diferenças sociais que atravessam a cidade inteira são minimizadas, forjando-se uma identidade citadina una para efetivar a preservação do patrimônio selecionado, protegendo-o dos "problemas" que a cidade enfrenta.

$\bigcirc$ paradigma do patrimônio como direito, por sua vez, se realiza na cidade por meio de ações inclusivas: o patrimônio é pensado amplamente no âmbito das políticas de reconhecimento e de reparação. Para compreender e agir nessa frente, políticas públicas intersetoriais de um Estado democrático de direito precisam ser implantadas. Aquilo que na perspectiva moderna é visto como problema é, de fato, tido aqui como constituinte do objeto patrimonializado. Rompendo com uma perspectiva linear do tempo, esse paradigma compreende a presença de passados sensíveis e difíceis no presente - passados esses tão ou mais indeterminados que o futuro. 
A salvaguarda e proteção do patrimônio cultural no seu sentido pleno é uma prática política, e o debate em torno do patrimônio está atravessado pela políitica em diferentes níveis. Logo, os temas trazidos aqui são fruto de ações em diversos setores, bem como de disputas e produções de sentidos e conhecimentos em várias frentes.

Neste artigo o desafio foi, por um lado, demonstrar esse entrelaçamento e, por outro, identificar, em aparentes contradições, a presença de paradigmas diversos, que fundamentam as ações e produzem tensões com disputas por posições no campo, conforme a visão de mundo de seus agentes. Na minha perspectiva, o caminho da transformação é, sem dúvida, aquele capaz de produzir uma cidade inclusiva, garantindo o direito à presença e ao presente. Para tanto, não podemos ser indiferentes ao passado.

Por que motivo aquelas medidas iniciadas nos anos 1980 parecem ter sido esvaziadas, circunscritas a foros de especialistas ou a limitados espaços da cidade? Por que o tema tende a voltar ao mesmo lugar de invisibilidade, limitando-se a uma área emblemática da cidade, de forma icônica? São perguntas para as quais espero ter contribuído não com respostas, mas apontando caminhos para um processo de construção coletiva do patrimônio cultural, especialmente no viés em que o Estado deveria atuar. 


\section{REFERENCIAS}

FONTE MANUSCRITA

ATA da $117^{a}$ Reunião do Conselho Consultivo do Patrimônio Histórico e Artístico Nacional realizada no dia 18 de novembro de 1985. Arquivo Central do Iphan, Serra da Barriga, Alagoas, processo 1069-T-1982. Rio de Janeiro: Iphan, 1985.

FONTES IMPRESSAS

APROVADO projeto para Monumento a Zumbi dos Palmares. Jornal dos Sports, Rio de Janeiro, p. 16,30 out. 1983 .

BRIZOLA inaugura Monumento a Zumbi. Jornal do Brasil, Rio de Janeiro, p. 8, 10 nov. 1986.

CYNTRÃO, Rita. Saúde não quer perder sua memória.Jornal dos Sports, Rio de Janeiro, p. 7, 23 dez. 1984. Seção Comando dos Bairros.

CYNTRÃO, Rita. Saúde ficou doente com longos anos de abandono. Jornal dos Sports, Rio de Janeiro, p. 5, 2 set. 1985. Seção Comando dos Bairros.

DARCY mostra a negro projeto de monumento. Jornal do Commercio, Rio de Janeiro, p. 14, 11 abr. 1986a. Caderno de Negócios.

JOSÉ Miguel quer erguer monumento a Zumbi no Rio. Jornal dos Sports, Rio de Janeiro, p. 14, 17 abr. 1983.

LUTHER King: José Miguel representa PDT em Atlanta. Jornal dos Sports, Rio de Janeiro, p. 3, 18 jan. 1986.

PERFEITO, Vera. Morro da Pedra do Sal, um doce pedaço do Rio. Jornal do Brasil, Rio de Janeiro, p. 5, 11 jan. 1985. Caderno Jovem.

SANTOS, Joaquim Ferreira dos. Saúde: os mistérios e a agonia de um velho bairro carioca. Jornal do Brasil, Rio de Janeiro, p. 7, 14 out. 1984. 
BOURDIEU, Pierre. Efeitos de lugar. In: BOURDIEU, Pierre (coord.). Miséria do mundo. Petrópolis: Vozes, 1997. p. 159-214.

BRASIL. Lei $\mathrm{n}^{\circ}$ 12.519, de 10 de novembro de 2011. Institui o Dia Nacional de Zumbi e da Consciência Negra. Diário Oficial da União, Brasília, DF, p. 7, 11 nov. 2011.

CALABRE, Lia. Políticas culturais no Brasil: dos anos 1930 ao século XXI. Rio de Janeiro: Editora FGV, 2009.

CARVALHO, José Murilo de. A formação das almas: o imaginário da República no Brasil. São Paulo: Companhia das Letras, 1990.

CHUVA, Márcia. Os arquitetos da memória: sociogênese das práticas de preservação do patrimônio cultural no Brasil. Rio de Janeiro: Ed. UFRJ, 2009.

CHUVA, Márcia. Pesquisa: a pesquisa no Iphan: conhecimento, legitimidade e ação política. In: REZENDE, Maria Beatriz; GRIECO, Bettina; TEIXEIRA, Luciano; THOMPSON, Analucia (orgs.). Dicionário Iphan de patrimônio cultural. Rio de Janeiro: Copedoc/Iphan, 2014. p. 1-28. Disponível em: <https://bit.ly/2TRXZIK>. Acesso em: 3 nov. 2020.

CHUVA, Márcia. Parque do Flamengo: projetar a cidade, desenhando patrimônio. Anais do Museu Paulista, São Paulo, v. 25, n. 3, p. 139-166, 2017 a.

CHUVA, Márcia. Possíveis narrativas sobre duas décadas de patrimônio: de 1982-2002. Revista do Patrimônio Histórico e Artístico Nacional, Brasília, DF, n. 35, p. 79-103, 2017b.

CONDURU, Roberto. Das casas às roças: comunidades de candomblé no Rio de Janeiro desde o fim do século XIX. Topoi, Rio de Janeiro, v. 11, n. 21, p. 178-203, 2010.

DIAS, Welbia Carla. Boletim Sphan/FNPM: um espaço de comunicação do patrimônio cultural. 2012. Dissertação (Mestrado em Preservação do Patrimônio Cultural) - Instituto do Patrimônio Histórico e Artístico Nacional, Rio de Janeiro, 2012.

FARIA, Maria Lucia Borges de. Preservação do patrimônio cultural urbano no "Porto Maravilba", Rio de Janeiro: disputas e deslocamentos de sentido nas políticas, práticas e instrumentos. 2016. Tese (Doutorado em Arquitetura e Urbanismo) - Universidade Federal Fluminense, Niterói, 2016. 
FERRAZ, Eucanaã. O tombamento de um marco da africanidade carioca: a Pedra do Sal. Revista do Patrimônio Histórico e Artístico Nacional, Brasília, DF, n. 25, p. 335-339, 1997.

FONSECA, Maria Cecília Londres. O patrimônio em processo. Rio de Janeiro: UFRJ; Brasília, DF: Iphan, 1997.

FONSECA, Maria Cecília Londres. Para além da pedra e cal: por uma concepção ampla de patrimônio cultural. In: ABREU, Regina; CHAGAS, Mário (orgs.). Memória e patrimônio: ensaios contemporâneos. Rio de Janeiro: DP\&A, 2003. p. 56-76.

FUNARI, Pedro Paulo A. Os desafios da destruição e conservação do Patrimônio Cultural no Brasil. Trabalhos de Antropologia e Etnologia, Porto, v. 41, n. 1-2, p. 23-32, 2001.

GREENBLATT, Stephen. O novo historicismo: ressonância e encantamento. Revista Estudos Históricos, Rio de Janeiro, v. 4, n. 8, p. 244-261, 1991.

GRINBERG, Keila. O mundo não é dos espertos: história pública, passados sensíveis, injustiças históricas. História da Historiografia, Mariana, v. 12, n. 31, p. 145-176, 2019.

HARTOG, François. Tempo e patrimônio. Varia História, Belo Horizonte, v. 22, n. 36, p. 261$273,2006$.

HARTOG, François. Regimes de historicidade: presentismo e experiências do tempo. Belo Horizonte: Autêntica, 2013.

INSTITUTO BRASILEIRO DE GEOGRAFIA E ESTATÍSTICA. Censo 2010: aglomerados subnormais: informações territoriais. Rio de Janeiro: IBGE, 2013.

INSTITUTO DO PATRIMÔNIO HISTÓRICO E ARTÍSTICO NACIONAL. Sítio Arqueológico Cais do Valongo: proposta de inscrição na Lista do Patrimônio Mundial. Brasília, DF: Iphan, 2016. Disponível em: <https://bit.ly/3oPF93f>. Acesso em: 29 maio 2020.

INSTITUTO ESTADUAL DO PATRIMÔNIO CULTURAL. Processo de Tombamento E-18/300.048/84: Pedra do Sal, 1984. Rio de Janeiro: Inepac, 1984.

OLIVEIRA, Raul Lanari. O patrimônio por escrito. A política editorial do Serviço do Patrimõnio Histórico e Artístico nacional (1937-1945). Belo Horizonte: Livramento, 2018. 
LARA, Silvia Hunold. Zumbi dos Palmares e de todos nós. Centro de Pesquisa em História Social da Cultura, Campinas, 14 maio 2020. Disponível em: https://bit.ly/3oWEb4Y. Acesso em: 3 nov. 2020.

LAVINAS, Laís. Um animal político na cultura brasileira: Aloísio Magalhães e o campo do patrimônio cultural no Brasil (anos 1966-1982). 2014. Dissertação (Mestrado em História) Universidade Federal do Estado do Rio de Janeiro, Rio de Janeiro, 2014.

LODI, Cristina Vereza (coord.). Dossiê da candidatura da cidade do Rio de Janeiro a paisagem cultural brasileira. Brasília, DF: Iphan, 2011. Disponível em: <https://bit.ly/318rqCp>. Acesso em: 29 maio 2020.

MARINS, Paulo César Garcez. Novos patrimônios, um novo Brasil? Um balanço das políticas patrimoniais federais após a década de 1980. Estudos Históricos, Rio de Janeiro, v. 29, n. 57, p. 9-28, 2016.

MATTOS, Hebe; ABREU, Martha. Relatório histórico-antropológico sobre o Quilombo da Pedra do Sal: em torno do samba, do santo e do porto. In: INSTITUTO NACIONAL DE COLONIZAÇÃO E REFORMA AGRÁRIA. Relatório técnico de identificação e delimitação da comunidade remanescente do Quilombo de Pedra do Sal. Rio de Janeiro: Incra, 2010. p. 12-92.

MATTOS, Hebe; GRINBERG, Keila; ABREU, Martha. Que diferença faz a perspectiva da história pública nos estudos sobre escravidão? In: MAUAD, Ana; SANTHIAGO, Ricardo; BORGES, Viviane (orgs.). Que história pública queremos? São Paulo: Letra e Voz, 2018. p. 229-237.

MOREIRA, Clarissa da Costa. A cidade contemporânea, entre a tabula rasa e a preservação: cenários para o Porto do Rio de Janeiro. São Paulo: Unesp, 2004.

MOTTA, Lia. Patrimônio urbano e memória social: práticas discursivas e seletivas de preservação cultural: 1975 a 1990. 2000. Dissertação (Mestrado em Memória Social e Documento) - Universidade Federal do Estado do Rio de Janeiro, Rio de Janeiro, 2000.

NASCIMENTO, Flávia Brito do. Patrimônio cultural e escrita da história: a hipótese do documento na prática do Iphan nos anos 1980. Anais do Museu Paulista, São Paulo, v. 24, n. 3, p. 121-147, 2016.

NASCIMENTO, Flávia Brito do; MARINS, Paulo Garcez (orgs.). Dossiê: o PCH, Programa de Cidades Históricas: um balanço após 40 anos. Anais do Museu Paulista. São Paulo, v. 24, n. 1, 2016. 
PAI RODNEY. Consciência negra é coisa de preto? Carta Capital, São Paulo, 17 nov. 2017. Disponível em: https://bit.ly/389kSzu. Acesso em: 3 nov. 2020.

PAIVA, Marcelo Cardoso de. O Brasil segundo o Iphan: a preservação do patrimônio cultural brasileiro durante a gestão de Gilberto Gil no MinC (2003-2008). 2019. Tese (Doutorado em Arquitetura e Urbanismo) - Universidade de São Paulo, São Paulo, 2019.

RIBEIRO, Adelia Miglievich; MATIAS, Glauber Rabelo. A universidade necessária em Darcy Ribeiro: notas sobre um pensamento utópico. Ciências Sociais Unisinos, São Leopoldo, v. 42, n. 3, p. 199-205, 2006.

REALI, Miguel. Tombamento e preservação do patrimônio artístico e cultural Parecer. $R D A-$ Revista de Direito Administrativo, Rio de Janeiro, v. 261, p. 255-266, set./dez. 2012.

REVISTA DO PATRIMÔNIO HISTÓRICO E ARTÍSTICO NACIONAL. Rio de Janeiro: Iphan, n. 19, 1984a.

REVISTA DO PATRIMÔNIO HISTÓRICO E ARTÍSTICO NACIONAL. Rio de Janeiro: Iphan, n. 20, 1984b.

REVISTA DO PATRIMÔNIO HISTÓRICO E ARTÍSTICO NACIONAL. Rio de Janeiro: Iphan, n. 21, 1986.

REVISTA DO PATRIMÔNIO HISTÓRICO E ARTÍSTICO NACIONAL. Rio de Janeiro: Iphan, n. 22, 1987.

RIBEIRO, Darcy. A universidade necessária. Rio de Janeiro, Paz e Terra, 1975.

RICOEUR, Paul. A memória, a bistória, o esquecimento. Campinas: Unicamp, 2007.

SANT'ANNA, Márcia. Da cidade-monumento à cidade-documento: a trajetória da norma de preservação de áreas urbanas no Brasil (1937-1990). Salvador: Oiti Editora, 2014.

SILVA, Francisco Carlos Teixeira da. A modernização autoritária: do golpe militar à redemocratização 1964/1984. In: LINHARES, Maria Yedda (org.). História geral do Brasil. Rio de Janeiro: Campus, 2000.

SOARES, Mariza de Carvalho. Nos atalhos da memória: Monumento a Zumbi. In: KNAUSS, Paulo (org.). Cidade vaidosa: imagens urbanas do Rio de Janeiro. Rio de Janeiro: 7 Letras, 1999. p. $117-135$. 
THOMPSON, Analucia; LEAL, Cláudia F. Baeta; SORGINE, Juliana; TEIXEIRA, Luciano dos Santos. História e civilização material na Revista do Patrimônio. Revista do Patrimônio Histórico e Artístico Nacional, Brasília, DF, n. 34, p. 167-197, 2012.

VELHO, Gilberto. Antropologia e patrimônio cultural. Revista do Patrimônio Histórico e Artístico Nacional, Rio de Janeiro, n. 20, p. 37-39, 1984.

VELHO, Gilberto. A grande cidade brasileira: sobre heterogeneidade e diversidade culturais. Revista do Patrimônio Histórico e Artístico Nacional, Rio de Janeiro, n. 21, p. 49-50, 1986.

VELHO, Gilberto. Patrimônio, negociação e conflito. Mana, Rio de Janeiro, v. 12, n. 1, p. 237248, 2006.

Artigo apresentado em $31 / 5 / 2020$. Aprovado em 30/7/2020.

\section{(cc) BY}

